\title{
Purkinje Cell Survival Is Differentially Regulated by Metabotropic and lonotropic Excitatory Amino Acid Receptors
}

\author{
Howard T. J. Mount, Cheryl F. Dreyfus, and Ira B. Black \\ Department of Neuroscience and Cell Biology, Robert Wood Johnson Medical School, UMDNJ, Piscataway, New Jersey \\ 08854-5635
}

\begin{abstract}
We previously reported that trophic factors and neurotransmitters in concert regulate survival of cultured cerebellar Purkinje cells. In particular, excitatory amino acid (EAA) transmitters and NGF increased survival, whereas neither alone was effective. In the present studies, we sought to identify molecular mechanisms through which EAAs participate in the survival-promoting interaction.

Initially, we characterized the potential role of ionotropic EAA receptors by exposing cultures to the antagonists MK801, D-2-amino-5-phosphonovaleric acid, and 6,7-dinitroquinoxalinedione. Each increased cell number, suggesting that endogenous ionotropic activity decreased survival. To determine whether metabotropic EAA receptor stimulation modulates survival, the metabotropic agonist ACPD ([1S,3R]1-aminocyclopentane-1,3-dicarboxylic acid; $1 \mu \mathrm{M}$ ) was tested. ACPD alone had no effect on survival. However, simultaneous exposure to ACPD and NGF significantly increased Purkinje number. Moreover, this increase in survival was blocked by L-AP3 [L(+)-2-amino-3-phosphonopropionic acid; $1 \mu \mathrm{M}]$, a putative antagonist of certain metabotropic responses. L-AP3 also reduced cell number in the absence of exogenous EAA. Thus, endogenous metabotropic stimulation is normally necessary for survival. In sum, these studies reveal a novel mechanism whereby an excitatory neurotransmitter shapes neural development by simultaneous trophic and regressive actions that are, respectively, mediated by metabotropic and ionotropic EAA receptors.
\end{abstract}

IKey words: cerebellar Purkinje cells, dissociated cell culture, NGF, aspartate, metabotropic receptor, NMDA receptor, excitatory amino acids]

The in vivo survival and differentiation of cerebellar Purkinje cells are affected by multiple epigenetic factors (see review by Ito, 1984). These include the excitatory innervation of climbing fibers projecting from the inferior olive and of parallel fibers, the axons of cerebellar granule cells. Loss of these inputs, through olivary or granule cell ablation (Bradley and Berry, 1976; Sotelo

\footnotetext{
Received Sept. 11, 1992; revised Jan. 13, 1993; accepted Feb. 10, 1993.

This work was supported by the Scottish Rite Schizophrenia Research Program (N.M.J., USA) and by NIH Grants NS 10259 and HD 23315. H.T.J.M. holds a postdoctoral fellowship from the Fonds de Recherche en Santé du Québec (Canada), and I.B.B. is a recipient of a McKnight Research Project Award.

Correspondence should be addressed to Howard T. J. Mount, Ph.D., Department of Neuroscience and Cell Biology, Robert Wood Johnson Medical School, UMDNJ, 679 Hoes Lane, Piscataway, NJ 08854-5635.

Copyright (C) 1993 Society for Neuroscience $0270-6474 / 93 / 133173-07 \$ 05.00 / 0$
}

and Arsenio-Nunes, 1976; Crepel et al., 1980), pharmacologic blockade (Vogel et al., 1990; Rabacchi et al., 1992), or mutation (Rakic and Sidman, 1973; Sotelo, 1975; Sadler and Berry, 1989), can result in degeneration or aberrant development of Purkinje cells. Neurotrophic factors may also play a role in Purkinje ontogeny. The transient expression of NGF in cerebellum (Lu et al., 1989) and the coincident expression of receptors for NGF and related neurotrophins by developing Purkinje cells (Eckenstein, 1988; Schatteman et al., 1988; Yan and Johnson, 1988; Cohen-Cory et al., 1989; Klein et al., 1990; Wanaka and Johnson, 1990) are consistent with such a role.

In previous work, we examined how simultaneous exposure to afferent excitatory transmitter and neurotrophic factor might regulate Purkinje development. Fetal rat Purkinje cells were grown in dissociated primary culture in the presence of NGF and/or excitatory amino acid (EAA) putative transmitters of the innervating fibers (Cohen-Cory et al., 1991). We found that Purkinje survival and morphologic differentiation were enhanced by the combined administration of EAA and NGF. Neither EAA nor NGF was effective alone.

In the experiments described in this article, our objective was to identify EAA receptors involved in the regulation of Purkinje survival to begin characterizing the molecular triggers that confer responsiveness to the survival-promoting action of NGF. EAAs activate multiple ionotropic receptors as well as a G-protein-linked metabotropic receptor. The ionotropic category includes three major subtypes, each named for its preferred agonist (the NMDA, quisqualate/AMPA, and kainate receptors). Ionotropic and metabotropic receptors have been identified on Purkinje cells ex vivo (Dupont et al., 1987; Garthwaite et al., 1987; Sekiguchi et al., 1987; Huang et al., 1990; Llano et al., 1991; Masu et al., 1991), and in dissociated cell culture (Krupa and Crepel, 1990; Linden et al., 1991; Yuzaki and Mikoshiba, 1992). To assess how stimulation of these receptors might modulate Purkinje survival, cells were maintained in the presence of NGF and EAA receptor subtypes were selectively stimulated or antagonized. Our data indicate that low concentrations of EAA may simultaneously exert survival-promoting and survival-limiting effects through stimulation of metabotropic and ionotropic receptors, respectively.

\section{Materials and Methods}

Cell culture. Dissociated Purkinje cell cultures were prepared from embryonic day 18 Sprague-Dawley rats, as previously described (CohenCory et al., 1991). Cerebella were collected in $2 \mathrm{ml}$ of culture medium and mechanically dissociated by gentle tituration in a flame-polished Pasteur pipette. The medium consisted of Minimum Essential Medium containing Earle's salts and $2 \mathrm{~mm}$ glutamine (MEM; GIBCO, Grand Island, NY) and was supplemented with heat-inactivated horse serum 


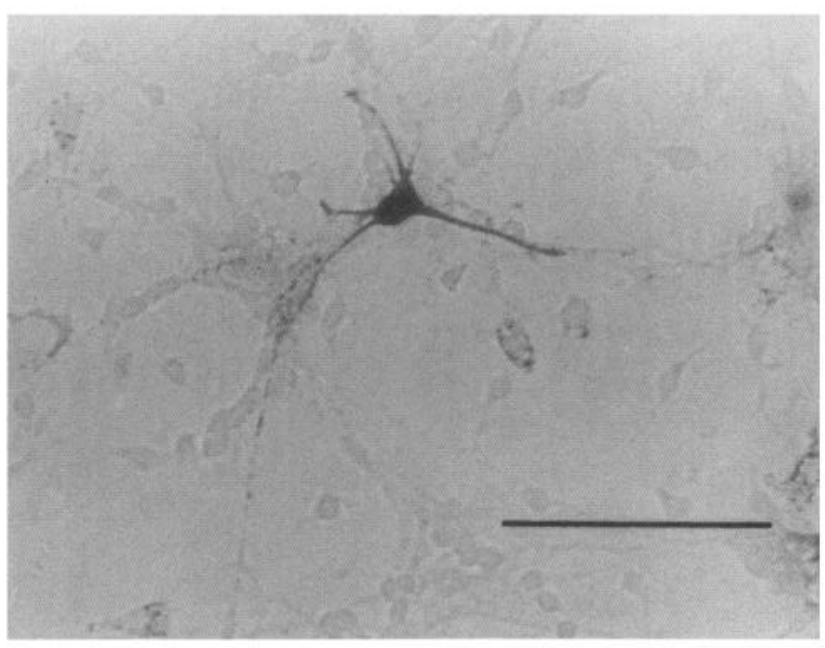

Figure 1. Visualization of a Purkinje cell in culture by immunocytochemical staining with $\mathrm{CaBP}$ antibody. E18 rat cerebellar cells were grown for $6 \mathrm{~d}$, under control conditions. Scale bar, $100 \mu \mathrm{m}$.

$(10 \% \mathrm{v} / \mathrm{v} ; \mathrm{GIBCO})$, glucose $(6 \mathrm{mg} / \mathrm{ml})$, penicillin $(0.5 \mathrm{U} / \mathrm{ml})$, and streptomycin $(0.5 \mu \mathrm{g} / \mathrm{ml})$. Cell suspensions were diluted with additional medium to $1 \times 10^{6}$ cells $/ \mathrm{ml}$ and grown in poly-D-lysine-coated multiwell culture plates $(12 \times 23 \mathrm{~mm}$ wells/plate $)$ at a density of $6 \times 10^{5}$ cells/ well. Cultures were maintained for $6 \mathrm{~d}$ without media change, at $37^{\circ} \mathrm{C}$ in a $95 \%$ air, $5 \% \mathrm{CO}_{2}(\mathrm{v} / \mathrm{v})$ humidified atmosphere. NGF and all EAA agonists and antagonists were added at the time of plating.

Immunocytochemistry. Purkinje survival was determined by counting cells immunocytochemically stained with antisera to vitamin D-dependent calcium-binding protein (CaBP; calbindin). Cells were rinsed once with $0.1 \mathrm{M}$ phosphate-buffered saline and fixed at $4^{\circ} \mathrm{C}$ for $2 \mathrm{hr}$ in $4 \%$ paraformaldehyde (in $0.1 \mathrm{~m}$ phosphate buffer, $\mathrm{pH}$ 7.6). A polyclonal antibody to CaBP, generously provided by Dr. S. Christakos (New Jersey Medical School, UMDMJ, Newark, NJ), was used at a dilution of 1:2000 (Christakos et al., 1987). Staining was visualized by the avidin-biotin complex $(\mathrm{ABC})$ technique, using biotinylated secondary antibodies and reagents (Vectastain ABC kit) from Vector Labs (Burlingame, CA) (see Fig. 1).

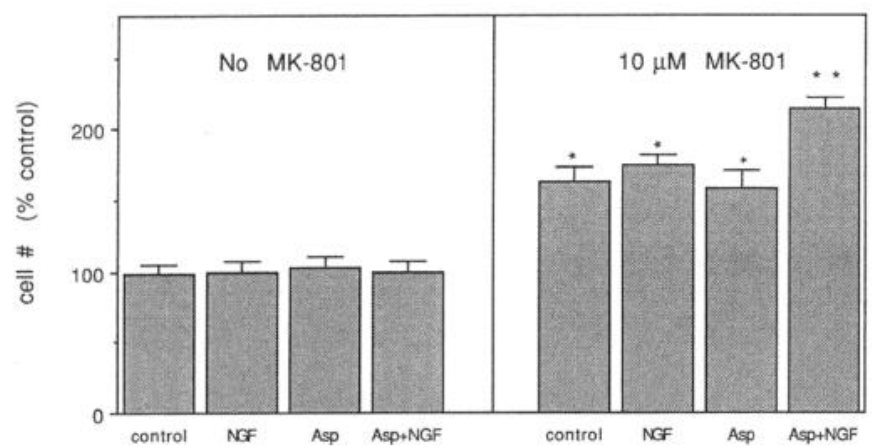

Figure 2. Effects of aspartate $(A s p ; 1 \mu \mathrm{M})$ and NGF $(1.5 \mu \mathrm{g} / \mathrm{ml})$ on Purkinje survival in the presence or absence of the noncompetitive NMDA receptor antagonist MK-801 $(10 \mu \mathrm{M})$. Embryonic day 18 rat cerebellar cells were grown in the presence of test compounds for $6 \mathrm{~d}$, and the Purkinje subpopulation was identified by immunohistochemical staining for $\mathrm{CaBP}$. The number of $\mathrm{CaBP}^{+}$cells in each culture was expressed as a percentage of the number of cells under control conditions in the absence of MK-801. Reported observations are means of three independent experiments, each performed in triplicate $(n=9)$. The overall number of cells in control cultures from the three experiments was $188 \pm 11$ (mean \pm SEM). An asterisk denotes a difference from control in the absence of MK-801 $(p<0.05)$; a double asterisk denotes a difference from control in the presence or absence of MK-801 $(p<$ $0.05)$.

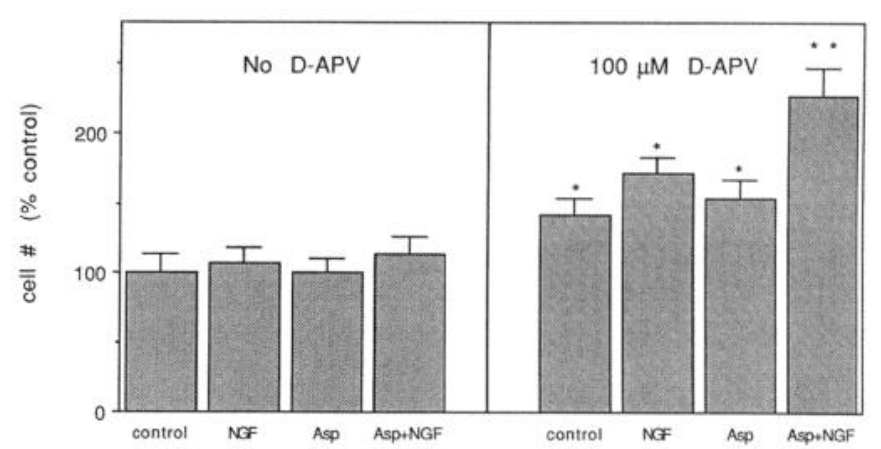

Figure 3. Effects of the competitive NMDA receptor antagonist D-APV $(100 \mu \mathrm{M})$ on Purkinje cell survival in the presence of aspartate (Asp; 1 $\mu \mathrm{M})$ and/or NGF $(1.5 \mu \mathrm{g} / \mathrm{ml})$. Cultures were grown for $6 \mathrm{~d}$, and the Purkinje subpopulation was identified and counted as described in Figure 2. Reported observations are means of two independent experiments, each performed in triplicate $(n=6)$. Data from each experiment were normalized to percentages of cell number in respective control cultures, grown in the absence of D-APV. The overall number of cells in control cultures from the two experiments was $259 \pm 78$ (mean \pm SEM). An asterisk denotes a difference from control in the absence of D-APV $(p<0.05)$; a double asterisk denotes a difference from control in the presence or absence of D-APV $(p<0.05)$.

Data analysis. $\mathrm{CaBP}^{+}$cells were counted in 30 fields, covering approximately $24 \%$ of culture well surface area. Raw data were transformed to percentages of cell number in sister control wells (no exogenous EAA agonists, antagonists, or NGF). Figures present mean data from two or more independent experiments, each performed at least in triplicate. Statistical analysis consisted of single-factor ANOVA and post hoc Fisher's protected least significant difference comparisons.

Chemicals. NGF was purified from mouse salivary gland, as previously described (Mobley et al., 1976), and bioactivity of the purified peptide was confirmed in assays of basal forebrain choline acetyltransferase activity and of neurite outgrowth from cultured dorsal root ganglia. $(5 R, 10 S)-(+)-5$-methyl-10,11-dihydro-5H-dibenzo[a,d]cyclohepten-5,10-imine (MK-801) and 6,7-dinitroquinoxalinedione (DNQX) were obtained from Research Biochemicals (Natick, MA). L(+)-2-Amino-3-phosphonopropionic acid (L-AP3) and (1S,3R)-1aminocyclopentane-1,3-dicarboxylic acid (ACPD) were purchased from Tocris Neuramin (Bristol, England). D-2-Amino-5-phosphonovaleric acid (D-APV) and L-aspartate came from Sigma Chemical Co. (St. Louis, MO). Other chemicals were reagent grade and came from regular commercial sources.

\section{Results}

The putative excitatory transmitters of climbing and parallel fibers that innervate the Purkinje cells are, respectively, aspartate (Wiklünd et al., 1982; Kimura et al., 1985; see also review in Cuénod et al., 1989) and glutamate (Hirano and Hagiwara, 1988). At low concentrations $(\leq 10 \mu \mathrm{M})$, these EAAs activate ionotropic receptors of the NMDA subtype in dissociated cell culture (Mount et al., 1990a). Thus, we began by investigating the importance of NMDA receptor mechanisms to Purkinje survival.

\section{Effects of NMDA receptor antagonists on Purkinje survival}

In initial experiments, cells were grown in the presence of MK$801(10 \mu \mathrm{M})$, a potent, noncompetitive NMDA receptor antagonist (Wong et al., 1986). MK-801 increased CaBP+ cell number (Fig. 2), suggesting that tonic NMDA receptor activation curtailed in vitro Purkinje survival. When NGF $(1.5 \mu \mathrm{g} / \mathrm{ml})$ and aspartate $(1 \mu \mathrm{M})$ were combined in the presence of $\mathrm{MK}-801$, an additional significant increase in cell number was obtained. This increase did not involve NMDA receptor activation, since it 


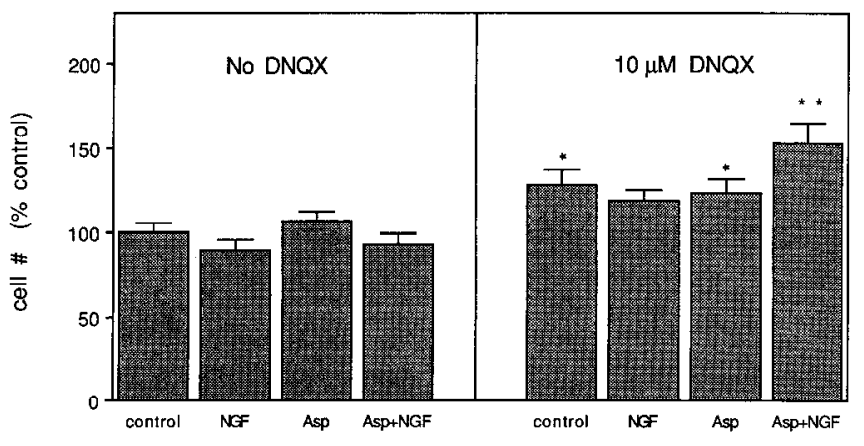

Figure 4. Effects of the non-NMDA receptor antagonist DNQX (10 $\mu \mathrm{M})$ on Purkinje cell survival in the presence of aspartate $(A s p ; 1 \mu \mathrm{M})$ and/or NGF $(1.5 \mu \mathrm{g} / \mathrm{ml})$. Cultures were grown for $6 \mathrm{~d}$, and the Purkinje subpopulation was identified and counted as described in Figure 2. Reported values are the means of three independent experiments, performed at least in triplicate $(n=9-15)$. Data from each experiment were normalized to percentages of cell number in respective control cultures, grown in the absence of DNQX. The overall number of cells in control cultures from the three experiments was $154 \pm 17$ (mean \pm SEM). An asterisk denotes a difference from control in the absence of DNQX $(p<0.05)$; a double asterisk denotes a difference from control in the presence or absence of DNQX $(p<0.05)$

was obtained in the presence of the NMDA receptor antagonist. It could also not be explained by differences in plating efficiency. In a representative experiment, $\mathrm{CaBP}^{+}$cell numbers in cultures treated with MK-801, NGF and aspartate were equivalent to those in controls at $24 \mathrm{hr}$ after plating (15563 \pm 364 and 15704 \pm 302 , respectively).

To confirm the survival-promoting effect of NMDA receptor blockade and the additional NMDA receptor-independent effect of aspartate/NGF, we tested D-APV $(100 \mu \mathrm{M})$, a selective competitive antagonist of the receptor (Davies and Watkins, 1982; Evans et al., 1982). This concentration of D-APV has been shown to block actions of NMDA, without affecting quisqualate or kainate responses in mesencephalic cell cultures (Mount et al., 1990h). Moreover, even $1 \mathrm{~mm}$ D-APV has been found to have no effect on metabotropic receptor-stimulated phosphoinositide hydrolysis in the developing cerebellum (Gombos et al., 1992). In our experiments, D-APV alone produced a significant increase in Purkinje survival that was similar to the effect of MK-801 (Fig. 3). Exposure to aspartate and NGF, in the presence of D-APV, produced a twofold increase in cell survival. These data confirm results obtained with MK-801, indicating that NMDA receptor activation decreases Purkinje survival, and does not mediate the aspartate/NGF interaction.

\section{Effects of a non-NMDA receptor antagonist on Purkinje survival}

Although the increase in cell number produced by simultaneous exposure to aspartate and NGF was not mediated by the NMDA receptor, it remained possible that non-NMDA ionotropic receptors were involved. To test this possibility, cells were grown in the presence of the potent non-NMDA antagonist DNQX (10 $\mu \mathrm{M}$; Honoré et al., 1988). DNQX alone produced a marginal, but significant, increase in Purkinje survival. When tested in the presence of DNQX, aspartate and NGF produced an additional increase in cell number (Fig. 4). The latter observations indicate that the survival-promoting interaction between aspartate and NGF does not involve non-NMDA ionotropic receptor mechanisms.

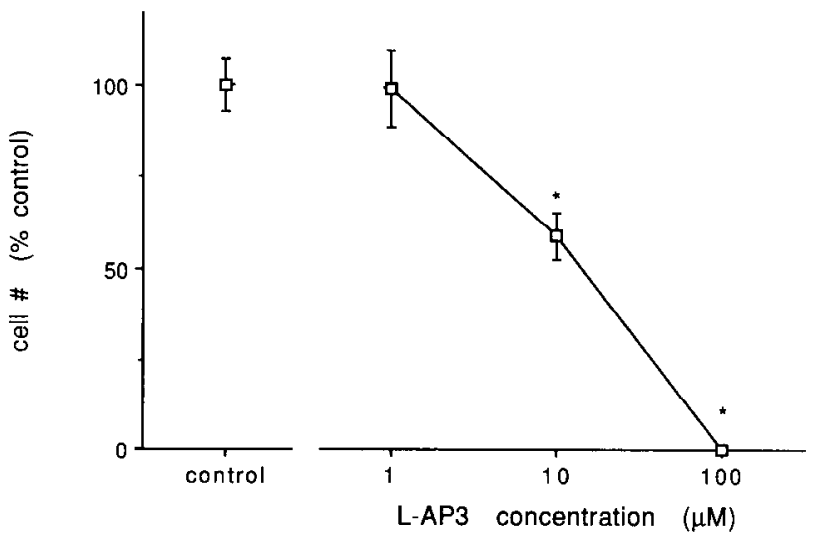

Figure 5. Effects of L-AP3 $(1-100 \mu \mathrm{M})$ on Purkinje cell survival. Cultures were grown in the presence of L-AP3 for $6 \mathrm{~d}$, and the Purkinje subpopulation was identified and counted as described in Figure 2. Reported observations are the means of two independent experiments, each performed at least in triplicate $(n=6-8)$. Data from each experiment were normalized to percentages of cell number in respective control cultures. The overall number of cells in control cultures from the three experiments was $202 \pm 22$ (mean \pm SEM). An asterisk denotes a difference from control (absence of L-AP3; $p<0.05$ ).

\section{Effects of metabotropic receptor ligands on Purkinje survival}

The increase in cell survival produced by exposure to MK-801, DNQX, or D-APV suggests that EAAs endogenous to the culture system activate ionotropic receptors, thereby decreasing survival. To assess whether tonic metabotropic receptor activation might influence Purkinje survival, cultures were exposed to L-AP3, a putative antagonist of some, but not all, metabotropic responses (Irving et al., 1990; Schoepp et al., 1990; but see Glaum et al., 1992; Yuzaki and Mikoshiba, 1992) (Fig. 5). At concentrations as low as $10 \mu \mathrm{M}, \mathrm{L}-\mathrm{AP} 3$ markedly decreased Purkinje survival. These findings suggest that endogenous metabotropic stimulation is required for in vitro survival.

Aspartate may activate metabotropic EAA receptors (Doble and Perrier, 1989; Masu et al., 1991; but see Sugiyama et al., 1989). Thus, the increase in cell number elicited by aspartate and NGF in the presence of an ionotropic receptor antagonist might involve metabotropic receptor stimulation. Consequently, we reexamined this response in the presence of L-AP3 (1 $\mu \mathrm{M})$. L-AP3 inhibited both the survival-promoting effect of aspartate/NGF in the presence of MK-801 and the increase in survival produced by NMDA receptor blockade alone (Fig. 6).

We also tested ACPD, a selective metabotropic agonist (Palmer et al., 1989; Manzoni et al., 1990). By itself, ACPD had no effect on survival (Fig. 7). However, the combination of ACPD $(1 \mu \mathrm{M})$ and NGF increased Purkinje cell number. The increase

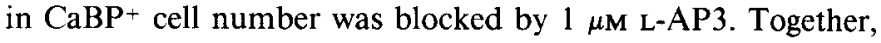
these data provide strong evidence that metabotropic receptor activation triggers Purkinje responsiveness to NGF. The increase could not be explained by differences in plating efficiency, since $\mathrm{CaBP}^{+}$cell numbers in cultures treated with ACPD and NGF were equivalent to those in controls, at $24 \mathrm{hr}$ after plating $(6629 \pm 168$ and $6683 \pm 284$, in a representative experiment).

\section{Discussion}

There is emerging evidence that EAAs play important roles in neuronal development in diverse brain areas. Fffects of EAAs range from synaptic strengthening and stimulation of neurite extension at low concentrations, to pruning of redundant con- 


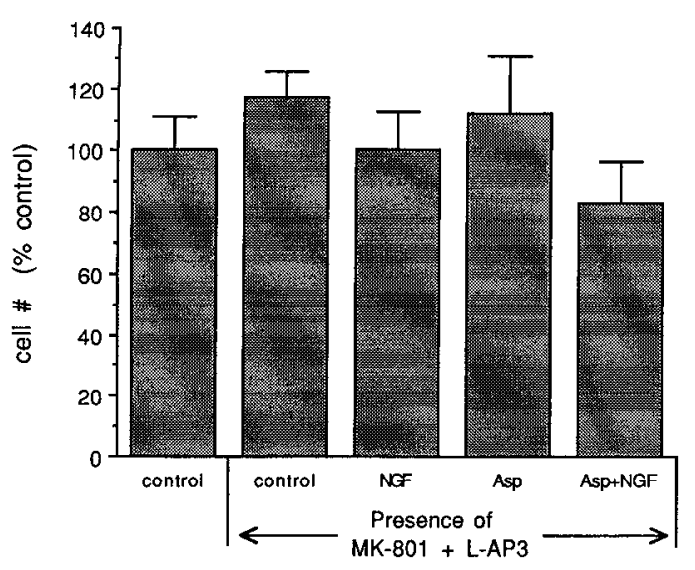

Figure 6. Effects of combining ionotropic (MK-801; $10 \mu \mathrm{M})$ and metabotropic (L-AP3; $1 \mu \mathrm{M}$ ) EAA receptor antagonists on Purkinje cell survival in the presence of aspartate $(A s p, 1 \mu \mathrm{M})$ and/or NGF $(1.5 \mu \mathrm{g} /$ $\mathrm{ml})$. Cultures were grown for $6 \mathrm{~d}$, and the Purkinje subpopulation was identified and counted as described in Figure 2. Reported values are the means of two independent experiments, each performed in triplicate $(n=6)$. Data from each experiment were normalized to percentages of cell number in respective control cultures. The overall number of cells in control cultures from the two experiments was $105 \pm 16$ (mean \pm $\mathrm{SEM})$. No significant differences from control in the absence of EAA receptor antagonists were detected.

nections and cell death at progressively higher concentrations (see reviews by Balázs and Hack, 1990; Mattson, 1990; McDonald and Johnston, 1990). In the present study, survival of Purkinje neurons was found to be dependent upon tonic metabotropic receptor activity in the cultures. In contrast, ionotropic receptor activation only decreased Purkinje survival. These data suggest that the balance between opposing effects of EAAs on the developing Purkinje cell is mediated by activation of distinct receptor subtypes. The experiments further reveal that metabotropic receptor activation serves to trigger responsiveness of Purkinje cells to the survival-promoting action of NGF.

\section{Ionotropic receptor activation reduces Purkinje survival}

Purkinje cells express multiple ionotropic EAA receptors (Krupa and Crepel, 1990; see also review by Crepel and Audinat, 1991). Receptors with high affinities for quisqualate and kainate have been identified on Purkinje cells of both the adult and neonate (Garthwaite et al., 1986). In contrast, NMDA receptors may be only transiently expressed during development. Responsiveness to NMDA is minimal at birth, increases during the first and sccond postnatal weeks, and then declines to an undetectable level in the adult (Dupont et al., 1987; Garthwaite et al., 1987; Audinat et al., 1990; Krupa and Crepel, 1990; but see Llano et al., 1990). The transient expression of NMDA receptors during development suggests that they may play a role in Purkinje ontogeny. Indeed, chronic neonatal exposure to the NMDA receptor antagonist APV disrupts both granule cell migration and the elaboration of Purkinje cell dendrites (Vogel et al., 1990). APV administration has also been shown to inhibit the normal regression of supernumerary climbing fiber-Purkinje cell synapses that occurs during cerebellar development (Rabacchi et al., 1992).

Dissociated Purkinje cell cultures provide an advantageous system to examine the role of NMDA receptors in development since agonist responses exhibit characteristic NMDA receptor pharmacology (Hockberger et al., 1989; Linden et al., 1991),

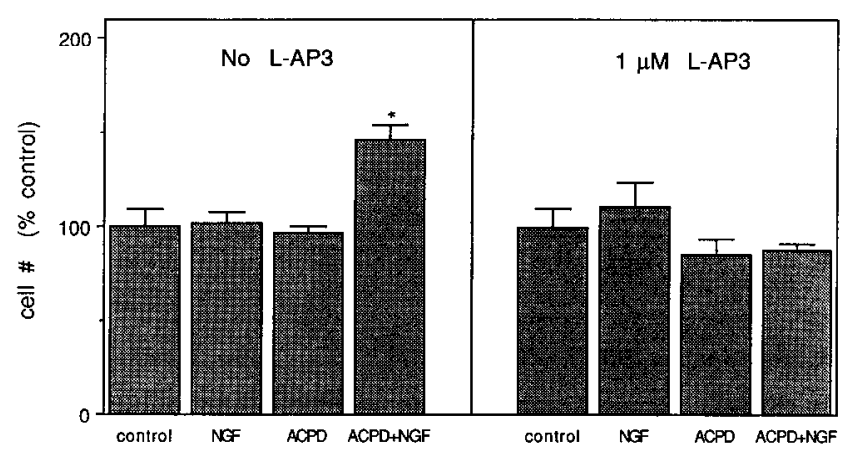

Figure 7. Effects of the metabotropic receptor agonist ACPD $(1 \mu \mathrm{M})$ and NGF $(1.5 \mu \mathrm{g} / \mathrm{ml})$ on Purkinje cell survival in the presence and absence of the metabotropic EAA receptor antagonist L-AP3 $(1 \mu \mathrm{M})$. Cultures were grown for $6 \mathrm{~d}$, and the Purkinje subpopulation was identified and counted as described in Figure 2. Reported values are the means of two independent experiments, each performed in triplicate ( $n$ $=6$ ). Data from each experiment were normalized to percentages of cell number in respective control cultures, grown in the absence of $\mathrm{L}-\mathrm{AP} 3$. The overall number of cclls in control cultures from the three experiments was $164 \pm 22$ (mean \pm SEM). An asterisk denotes a difference from control in the absence of L-AP3 $(p<0.05)$.

including blockade by MK-801 and APV (Linden et al., 1991). In our experiments, both MK-801 and D-APV promoted Purkinje survival. The inferred reduction in Purkinje cell number induced by tonic NMDA receptor activation contrasts with NMDA receptor-mediated increases in cerebellar granule cell survival (see review by Balázs and Hack, 1990). Thus, NMDA receptor-mediated responses to endogenous EAAs during cerebellar development are cell type specific.

The role of non-NMDA ionotropic receptors in regulating Purkinje survival is less clear. DNQX, a potent non-NMDA receptor antagonist, marginally increased Purkinje survival. However, all or part of this effect may be explained by allosteric antagonism of NMDA responses by DNQX, at a glycine coagonist site on the NMDA receptor complex (Birch et al., 1988; Foster, 1988). In support of the view that non-NMDA as well as NMDA receptors mediate EAA-induced cell loss, we have found that even low concentrations $(0.1-1 \mu \mathrm{M})$ of quisqualate or kainate reduced Purkinje cell number (H. T. J. Mount, C. F. Dreyfus, and I. B. Black, unpublished observations). These agonists are ineffective at the NMDA receptor (see reviews by Mayer and Westbrook, 1987; Collingridge and Lester, 1989).

In an earlier study (Cohen-Cory et al., 1991), we reported enhanced Purkinje survival in the presence of aspartate and NGF. We have subsequently found that an incrcasc in cell number elicited by coadministered aspartate and NGF is more consistently reproduced in the presence of an ionotropic receptor antagonist. These data suggest that distinct mechanisms underlie simultaneous opposing effects of EAAs on the developing Purkinje cell. The outcome of these opposing influences may be sensitive to manipulation of ionotropic receptor activity.

\section{Metabotropic receptor activation triggers responsiveness of Purkinje cells to NGF}

The survival effect of aspartate/NGF under conditions of ionotropic receptor blockade could be reproduced by NGF and ACPD, a selective metabotropic agonist, in the absence of ionotropic receptor antagonists. Both aspartate/NGF and ACPD/ NGF responses were blocked by L-AP3 $(1 \mu \mathrm{M})$. These data suggest that metabotropic receptors confer responsiveness to NGF. 
Metabotropic receptors are abundant in cerebellum; in situ hybridization has revealed prominent expression of metabotropic receptor mRNA by Purkinje cells (Masu et al., 1991). Receptor activation induces phosphoinositide hydrolysis (Sladeczek et al., 1985; Nicoletti et al., 1986; Weiss et al., 1988), and initiates a cascade of processes that result in mobilization of $\mathrm{Ca}^{2+}$ from intracellular stores (Murphy and Miller, 1988) and alteration of cellular $\mathrm{K}^{+}$conductances (Stratton et al., 1989; Charpak et al., 1990; Fagni et al., 1991; Vecil et al., 1991). Since metabotropic activation of certain $\mathrm{K}^{+}$currents should tend to reduce the efficacy of ionotropic receptor-induced excitation (Fagni et al., 1991), it is possible that metabotropic and ionotropic receptors might mediate opposing influences on neuronal survival, independent of NGF. For example, it has been reported that NMDA-induced neurotoxicity in cortical cell cultures is noncompetitively inhibited by ACPD (Koh et al., 1991). However, a similar mechanism cannot explain the present findings, since ACPD by itself did not enhance Purkinje cell number.

The decrease in Purkinje survival produced by higher concentrations of L-AP3 $(\leq 10 \mu \mathrm{M})$ suggests that tonic metabotropic receptor activation is required for $i n$ vitro Purkinje development. Metabotropic agonism may also be required for normal in vivo development, as receptor blockade caused cerebellar degeneration in mice treated with intraperitoneal AP3 on postnatal days 4-8 (Tizzano et al., 1991).

There is emerging evidence that very low concentrations of EAAs may exert pharmacologic effects that are distinct from those elicited by higher doses. For example, $1 \mu \mathrm{M}$ glutamate has been shown to induce transcription of the immediate-early gene c-fos in cerebellar granule cells, while $50 \mu \mathrm{M}$ glutamate did not (Manev et al., 1990). We have found that chronic exposure to very low concentrations $(1 \mu \mathrm{M})$ of aspartate and ACPD enhanced Purkinje survival (when tested in the presence of NGF), while concentrations above $10 \mu \mathrm{M}$ were less effective, or neurotoxic (data not shown). Moreover, these low dose effects were blocked by chronic exposure to a very low dose of L-AP3 $(1 \mu \mathrm{M})$. In contrast, a recent study of metabotropic receptor function in cultured Purkinje cells reported that acutc exposure to $2 \mathrm{~mm}$ L-AP3 did not block $\mathrm{Ca}^{2+}$ mobilization induced by $100 \mu \mathrm{M}$ ACPD and that $1 \mathrm{~mm}$ aspartate was inactive as a metabotropic agonist (Yuzaki and Mikoshiba, 1992). These findings suggest that metabotropic receptors mediate chronic low concentration EAA-induced actions that have a pharmacologic profile distinct from the higher-dose acute effect of intracellular $\mathrm{Ca}^{2+}$ mobilization. Precise distinction between these profiles will be facilitated by the development of more selective metabotropic receptor ligands.

\section{Metabotropic/ionotropic balance in the regulation of Purkinje survival}

Naturally occurring EAAs are active at both metabotropic and ionotropic receptors. Thus, the ultimate effect of an endogenous EAA agonist on Purkinje survival may be determined by the balance between opposing actions at distinct EAA reccptor subtypes. Differences between cells in the relative expression of receptors could result in Purkinje subpopulations that are differentially affected by EAA activity. Specificity of neuromodulatory influences might also contribute to the heterogeneity in susceptibility to tonic EAA activity. For example, cells that survived tonic EAA receptor activation may have been protected from ionotropic neurodegeneration by coincident inhibitory innervation.
Although cultured Purkinje cells have been shown to express multiple EAA receptors as well as receptors for NGF, it remains possible that effects on the Purkinje population were mediated indirectly. Since the dissociated cell cultures contained a variety of neuronal and glial elements in addition to Purkinje cells, it is possible that effects of EAAs upon the Purkinje population were mediated through molecules elaborated by other EAAresponsive cells in the culture. Future experiments with more purified Purkinje cell populations should facilitate the separation of indirect from direct actions of EAAs.

In summary, the present data indicate that aspartate, the putative EAA transmitter of innervating climbing fibers, regulates Purkinje survival through trophic and regressive influences that are, respectively, mediated by metabotropic and ionotropic EAA receptors. The metabotropic influence is mediated through an induction of responsiveness to neurotrophic factor. This raises the possibility that metabotropic stimulation regulates expression or function of a neurotrophic factor receptor(s) during Purkinje development. We are now actively investigating this hypothesis.

\section{References}

Audinat E, Knöpfel T, Gähwiler BH (1990) Responses to excitatory amino acids of Purkinje cells and neurones of the deep nuclei in cerebellar slice cultures. J Physiol (Lond) 430:297-313.

Balázs R, Hack N (1990) Trophic effects of excitatory amino acids in the developing nervous system. In: Excitatory amino acids and neuronal plasticity (Ben-Ari Y, ed), pp 221-228. New York: Plenum.

Birch PJ, Grossman CJ, Hayes AG (1988) Kynurenate and FG9041 have both competitive and non-competitive antagonist actions at excitatory amino acid receptors. Eur J Pharmacol 151:313-315.

Bradley P, Berry M (1976) The effects of reduced climbing and parallel fibre input on Purkinje cell dendritic growth. Brain Res 109:133-151.

Charpak S, Gähwiler BH, Do KQ, Knöpfel T (1990) Potassium conductances in hippocampal neurons blocked by excitatory amino-acid transmitter. Nature 347:765-767.

Christakos S, Rhoten WB, Feldman SC (1987) Rat calbindin D28K purification, quantitation, immunocytochemical localization and comparative aspects. In: Methods in enzymology, Vol 139 (Means AR, ed), pp 534-551. San Diego: Academic.

Cohen-Cory S, Dreyfus CF, Black IB (1989) Expression of high- and low-affinity nerve growth factor receptors by Purkinje cells in the developing rat cerebellum. Exp Neurol 105:104-109.

Cohen-Cory S, Dreyfus CF, Black IB (1991) NGF and excitatory neurotransmitters regulate survival and morphogenesis of cultured cerebellar Purkinje cells. J Neurosci 11:462-471.

Collingridge GL, Lester RA (1989) Fxcitatory amino acid receptors in the vertebrate central nervous system. Pharmacol Rev 40:143-210.

Crepel F, Audinat E (1991) Excitatory amino acid receptors of cerebellar Purkinje cells: development and plasticity. Prog Biophys Mol Biol 55:31-46.

Crepel F, Delhaye-Bouchard N, Dupont JL, Sotelo C (1980) Dendritic and axonal fields of Purkinje cells in developing $x$-irradiated rat cerebellum. A comparative study using intracellular staining with horse radish peroxidase. Neuroscience 5:333-347.

Cuénod M, Do K-Q, Vollenweider F, Zollinger M, Klein A, Streit P (1989) The puzzle of the transmitters in the climbing fibers. In: Experimental brain research series, Vol 17 (Strata P, ed), pp 161176. Berlin: Springer.

Davies J, Watkins JC (1982) Actions of $\mathrm{D}$ and $\mathrm{L}$ forms of 2-amino-5phosphonovalerate and 2-amino-4-phosphonobutyrate in the cat spinal cord. Brain Res 130:364-368.

Doble A, Perrier ML (1989) Pharmacology of excitatory amino acid receptors coupled to inositol phosphate metabolism in neonatal rat striatum. Neurochem Int 15:1-8.

Dupont JL, Gardette R, Crepel F (1987) Postnatal development of the chemosensitivity of rat cerebellar Purkinje cells to excitatory amino acids: an in vitro study. Dev Brain Res 34:59-68.

Eckenstein F (1988) Transient expression of NGF-receptor-like immunoreactivity in postnatal rat brain and spinal cord. Brain Res 446 : $149-154$ 
Evans RH, Francis AA, Hunt K, Oakes DJ, Watkins JC (1982) The effects of a series of $\omega$-phosphonic- $\alpha$-carboxylic amino acids on electrically evoked and amino acid induced responses in isolated spinal cord preparations. Br J Pharmacol 75:65-75.

Fagni L, Bossu JL, Bockaert J (1991) Activation of a large-conductance $\mathrm{Ca}^{2+}$-dependent $\mathrm{K}^{+}$channel by stimulation of glutamate phosphoinositide-coupled receptors in cultured cerebellar granule cells. Eur J Neurosci 3:778-789.

Foster A (1988) Quisqualate receptor antagonists. Nature 335:669670.

Garthwaite G, Yamini B Jr, Garthwaite J (1987) Selective loss of responsiveness to $N$-methyl-D-aspartate in rat cerebellum during development. Dev Brain Res 36:288-292.

Garthwaite J, Garthwaite G, Hajós F (1986) Amino acid neurotoxicity: relationship to neuronal depolarization in rat cerebellar slices. Neuroscience 18:449-460.

Glaum SR, Slater NT, Rossi DJ, Miller RJ (1992) Role of metabotropic glutamate (ACPD) receptors at the parallel fiber-Purkinje cell synapse. J Neurophysiol 68:1453-1462.

Gombos G, Levy O, de Barry J (1992) Developmental changes of EAA metabotropic receptor activity in rat cerebellum. Neuroreport 3:877-880.

Hirano T, Hagiwara S (1988) Synaptic transmission between rat cerebellar granule and Purkinje cells in dissociated cell culture: effects of excitatory-amino acid transmitter antagonists. Proc Natl Acad Sci USA 85:934-938.

Hockberger PE, Tseng H-Y, Connor JA (1989) Fura-2-measurements of cultured rat Purkinje neurons show dendritic localization of $\mathrm{Ca}^{2+}$ influx. J Neurosci 9:2272-2284.

Honoré T, Davies SN, Drejer J, Fletcher EJ, Jacobsen P, Lodge D, Nielsen FE (1988) Quinoxalinediones: potent competitive nonNMDA glutamate receptor antagonists. Science 241:701-703.

Huang PM, Bredt DS, Snyder SH (1990) Autoradiographic imaging of phosphoinositide turnover in brain. Science 249:802-804.

Irving AJ, Schofield JG, Watkins JC, Sunter DC, Collingridge GL (1990) $1 S, 3 R$-ACPD stimulates and L-AP3 blocks $\mathrm{Ca}^{2+}$ mobilization in rat cerebellar neurons. Eur J Pharmacol 186:363-365.

Ito $\mathrm{M}$ (1984) The cerebellum and neural control. New York: Raven.

Kimura H, Okamoto K, Sakai Y (1985) Pharmacological evidence for L-aspartate as the neurotransmitter of cerebellar climbing fibres in the guinea-pig. J Physiol (Lond) 365:103-119.

Klein R, Martin-Zanca D, Barbacid M, Parada LF (1990) Expression of the tyrosine kinase receptor gene $\operatorname{trk} B$ is confined to the murine embryonic and adult nervous system. Development 109:845-850.

Koh J-Y, Palmer E, Cotman CW (1991) Activation of the metabotropic glutamate receptor attenuates $N$-methyl-D-aspartate neurotoxicity in cortical cultures. Proc Natl Acad Sci USA 88:9431-9435.

Krupa M, Crepel F (1990) Transient sensitivity of rat cerebellar Purkinje cells to $N$-methyl-D-aspartate during development. A voltage clamp study in in vitro slices. Eur J Neurosci 2:312-316.

Linden DJ, Dickinson MH, Smeyne M, Connor JA (1991) A longterm depression of AMPA currents in cultured cerebellar Purkinje neurons. Neuron 7:81-89.

Llano I, Marty A, Armstrong CM, Konnerth A (1990) Synaptic- and agonist-induced excitatory currents of Purkinje cells in rat cerebellar slices. J Physiol (Lond) 434:183-213.

Llano I, Dreessen J, Kano M, Konnerth A (1991) Intradendritic release of calcium induced by glutamate in cerebellar Purkinje cells. Neuron 7:577-583

Lu B, Buck CR, Dreyfus CF, Black IB (1989) Expression of NGF and NGF receptor $m$ RNA in the developing brain. Evidence for local delivery and action of NGF. Exp Neurol 104:191-199.

Manev H, Costa E, Wroblewski JT, Guidotti A (1990) Abusive stimulation of excitatory amino acid receptors: a strategy to limit neurotoxicity. FASEB J 4:2789-2797.

Manzoni O, Fagni L, Pin J-P, Rassendren F, Poulat F, Sladeczek F, Bockaert J (1990) (trans)-1-Amino-cyclopentyl-1,3-dicarboxylate stimulates quisqualate phosphoinositide-coupled receptors but not ionotropic glutamate receptors in striatal neurons and Xenopus oocytes. Mol Pharmacol 38:1-6.

Masu M, Tanabe Y, Tsuchida K, Shigemoto R, Nakanishi S (1991) Sequence and expression of a metabotropic glutamate receptor. $\mathrm{Na}$ ture 349:760-765.

Mattson MP (1990) Excitatory amino acids, growth factors, and calcium: a teeter-totter model for neural plasticity and degeneration. In:
Excitatory amino acids and neuronal plasticity (Ben-Ari $Y$, ed), pp 211-220. New York: Plenum.

Mayer ML, Westbrook GL (1987) The physiology of excitatory amino acids in the vertebrate central nervous system. Prog Neurobiol 28: 197-276.

McDonald JW, Johnston MV (1990) Physiological and pathophysiological roles of excitatory amino acids during central nervous system development. Brain Res Rev 15:41-70.

Mobley WC, Schenker A, Shooter EM (1976) Characterization and isolation of proteolitically modified nerve growth factor. Biochemistry 15:5543-5551.

Mount H, Quirion R, Chaudieu I, Boksa P (1990a) Stimulation of dopamine release from cultured rat mesencephalic cells by naturally occurring excitatory amino acids: involvement of both $N$-methylD-aspartate (NMDA) and non-NMDA receptor subtypes. J Neurochem 55:268-275.

Mount H, Quirion R, Kohn-Alexander J, Boksa P (1990b) Subtypes of excitatory amino acid receptors involved in the stimulation of $\left[{ }^{3} \mathrm{H}\right]$ dopamine release from cell cultures of rat ventral mesencephalon. Synapse 5:271-280.

Murphy SN, Miller RJ (1988) A glutamate receptor stimulates $\mathrm{Ca}^{2+}$ mobilization in hippocampal neurons. Proc Natl Acad Sci USA 85: 8737-8741.

Nicoletti F, Wrobleski JT, Novelli A, Alho H, Guidotti A, Costa E (1986) The activation of inositol phospholipid metabolism as a signal transducing system for excitatory amino acids in primary cultures of cerebellar granule cells. J Neurosci 6:1905-1911.

Palmer E, Monaghan DT, Cotman CW (1989) trans-ACPD, a selective agonist of the phosphoinositide-coupled excitatory amino acid receptor. Eur J Pharmacol 166:585-587.

Rabacchi S, Bailly Y, Delhaye-Bouchard N, Mariani J (1992) Involvement of the $N$-methyl-D-aspartate (NMDA) receptor in synapse elimination during cerebellar development. Science 256:1823-1825.

Rakic P, Sidman RL (1973) Organization of the cerebellar cortex secondary to deficit of granule cells in weaver mutant mice. J Comp Neurol 152:133-162.

Sadler M, Berry M (1989) Topological link-vertex analysis of the growth of Purkinje cell dendritic trees in normal, reeler, and weaver mice. J Comp Neurol 289:260-283.

Schatteman GC, Gibbs L, Lanahan AA, Claude P, Bothwell M (1988) Expression of NGF receptor in the developing and adult primate central nervous system. J Neurosci 8:860-873.

Schoepp DD, Johnson BG, Smith ECR, McQuaid LA (1990) Stereoselectivity and mode of inhibition of phosphoinositide-coupled excitatory amino acid receptors by 2-amino-3-phosphonopropionic acid. Mol Pharmacol 38:222-228.

Sekiguchi M, Okamoto K, Sakai Y (1987) NMDA receptors on Purkinje cell dendrites in guinea pig cerebellar slices. Brain Res 437:402406.

Sladeczek F, Pin J-P, Récasens M, Bockaert J, Weiss S (1985) Glutamate stimulates inositol phosphate formation in striatal neurons. Nature 317:717-719.

Sotelo C (1975) Anatomical physiological and biochemical studies of the cerebcllum from mutant micc. II. Morphological study of ccrcbellar cortical neurons and circuits in the weaver mouse. Brain Res 94:19-44.

Sotelo C, Arsenio-Nunes ML (1976) Development of Purkinje cells in absence of climbing fibers. Brain Res 111:389-395.

Stratton KR, Worley PF, Baraban JM (1989) Excitation of hippocampal neurons by stimulation of glutamate Qp receptors. Eur J Pharmacol 173:235-237.

Sugiyama H, Ito I, Watanabe M (1989) Glutamate receptor subtypes may be classified into two major categories: a study on Xenopus oocytes injected with rat brain mRNA. Neuron 3:129-132.

Tizzanno JP, Schoepp D, Price MT, Olney J (1991) Widespread degeneration induced in the developing rodent CNS by $\mathrm{D}, \mathrm{L}-2$-amino-3phosphonopropionate (AP3). Soc Neurosci Abstr 17:70.

Vecil CG, Li PP, Warsh JJ (1991) Evidence for metabotropic excitatory amino acid receptor heterogeneity: developmental and brain regional studies. Soc Neurosci Abstr 17:70.

Vogel MW, McInnes M, Cline H (1990) Chronic exposure of the cerebella of neonatal mice to the NMDA receptor antagonist, AP5, disrupts Purkinje and granule cell development. Soc Neurosci Abstr 16:647.

Wanaka A, Johnson EM Jr (1990) Developmental study of nerve 
growth factor receptor mRNA expression in the postnatal rat cerebellum. Dev Brain Res 55:288-292.

Weiss S, Schmidt BH, Sebben M, Kemp DE, Bockaert J, Sladeczek F (1988) Neurotransmitter-induced inositol phosphate formation in neurons in primary culture. J Neurochem 50:1425-1433.

Wiklünd $G$, Toggenburger $G$, Cuénod $M$ (1982) Aspartate: possible neurotransmitter in cerebellar climbing fibers. Science 216:78-79.

Wong EHF, Kemp JA, Priestly T, Knight AR, Woodruff GN (1986)
The anticonvulsant MK- 801 is a potent $N$-methyl-D-aspartate antagonist. Proc Natl Acad Sci USA 83:7104-7108.

Yan Q, Johnson EM (1988) An immunohistochemical study of the nerve growth factor (NGF) receptor in developing rats. J Neurosci 8:3481-3498.

Yuzaki M, Mikoshiba K (1992) Pharmacological and immunocytochemical characterization of metabotropic glutamate receptors in cultured Purkinje cells. J Neurosci 12:4253-4263. 